\title{
A STUDY OF THE SERUM PHOSPHATASE IN BONE DISEASE
}

\author{
BY H. Q. WOODARD, GRAY H. TWOMBLY AND BRADLEY L. COLEY
}

(From the Memorial Hospital, New York City)

(Received for publication November 30, 1935)

Since the development of satisfactory methods of determining the phospholytic activity of the blood by Kay $(1,2)$ and by Bodansky and others $(3,4,5,6)$, there has been increasing interest in the relation of blood phosphatase to various pathological conditions. It is now fairly well established that the major portion of the phosphatase in the blood is contained in the erythrocytes (1, $7,8,9,10)$. Of the phosphatase in the serum, a part may well originate in the bones, and a part in the liver, kidney, and intestinal mucosa (11, $12)$, as these tissues are rich in phosphatase. The serum phosphatase of non-osseous origin is raised by ingestion of carbohydrates, greatly raised by obstructive jaundice, and lowered by starvation and by the ingestion of proteins (13, $14,15,16,17)$. The serum phosphatase of osseous origin is greatly increased in bone diseases associated with excessive bone and osteoid formation $(1,4,18,19,20,21)$.

The rise in serum phosphatase in some types of bone tumors is apparently due to the production of large quantities of the enzyme by the neoplastic tissue or adjacent periosteum, and the removal of part of the enzyme by the blood stream. It has been reported by Kay (1), Bodansky and Jaffe (4), Simmons and Franseen $(20,21)$ and others that this increase in serum phosphatase is of use in the diagnosis of bone cancer, and that serial determinations made during the course of treatment are important in prognosis. In the present paper further evidence on these questions is presented.

\section{METHOD}

We have used Bodansky's modification of Kay's procedure with some changes $(2,3)$. Fifteen cc. of blood were allowed to clot for $1 / 2$ to 1 hour, and centrifuged. The serum was then decanted and centrifuged again to remove all cells. One cc. of serum was then added to $9 \mathrm{cc}$. of sodiumbeta-glycerophosphate and sodium barbiturate buffer, and incubated for 20 minutes to 2 hours, the time depending on the phospholytic activity anticipated. A sample was then withdrawn for $\mathrm{pH}$ determination, and 10 per cent trichloracetic acid was added to the remainder of the mixture. Meanwhile, $1.5 \mathrm{cc}$. of serum had been added to $13.5 \mathrm{cc}$. of 5 per cent trichloracetic acid for inorganic phosphorus determination. The trichloracetic acid precipitates were removed by filtration, and the inorganic phosphorus in the filtrate determined colorimetrically by means of molybdic and sulphuric acid and stannous chloride, all determinations being run in duplicate.

Two modifications of Bodansky's procedure were introduced. The first was made because we were unable to obtain blank solutions of molybdic and sulphuric acids and stannous chloride which were free from color. Accordingly we prepared 3 blanks, $\left(B_{1}\right)$ containing the color reagents molybdic and sulphuric acids and stannous chloride in the concentration in which they appeared in the standard phosphate solution; $\left(\mathrm{B}_{2}\right)$ containing the color reagents, substrate, and trichloracetic acid in the same concentration as for the phosphatase determination; $\left(\mathrm{B}_{3}\right)$ containing color reagents and trichloracetic acid in the same concentration as for the determination of inorganic phosphorus. The apparent phosphorus concentrations of these blanks were then read against the standard and applied as correction to the standard and unknown solutions. It was found that, when this was done, the deviation from Beer's law in known standard phosphate solutions of different concentrations was very much less than that reported by Bodansky. The correction for substrate plus trichloracetic acid was less than Bodansky's for low phosphorus concentrations and greater for high concentrations. The correction for trichloracetic acid alone was less than Bodansky's. Appropriate correction curves were prepared, and those of Bodansky were not used. Calculations made by both Bodansky's corrections and the present ones for a series of 67 phosphatase determinations showed an average variation of only 2 per cent, but, since the blanks for 
different solution lots varied considerably, the differences between the values for individual determinations calculated by the two methods amounted to as much as 10 per cent.

The reproducibility of the method was studied by finding the average difference between duplicate determinations on the same trichloracetic acid filtrate or standard phosphate solution. The average differences between duplicates for 100 unselected solutions in each series were:

\begin{tabular}{|c|c|}
\hline $\begin{array}{c}\text { Average } \\
\text { difference } \\
\text { per cent }\end{array}$ & $\begin{array}{c}\text { Range } \\
\text { per cent }\end{array}$ \\
\hline 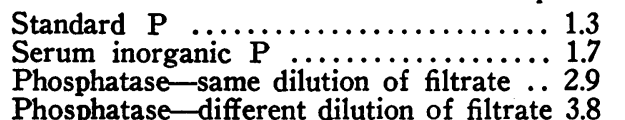 & $\begin{array}{l}0 \text { to } 5.5 \\
0 \text { to } 5.6 \\
0 \text { to } 10.7 \\
0 \text { to } 13.5\end{array}$ \\
\hline
\end{tabular}

The last includes determinations made at the limits of concentration at which the method can be used.

For duplicate determinations made on different samples of the same serum, the average differences for 30 sera were

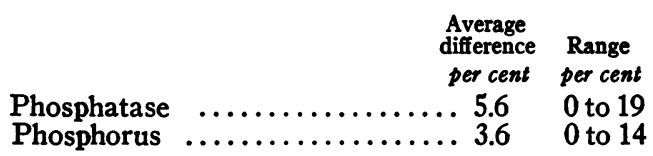

The experimental error of the method is thus not large enough to affect the clinical significance of the results.

The second modification of Bodansky's method which was employed consisted in the determination of the $\mathrm{pH}$ of the serum-substrate mixture at the end of each incubation. Preliminary work showed that the buffering action of different sera varied so much that, when two sera were mixed with the same substrate at the same concentration, the $\mathrm{pH}$ of the mixture differed by as much as $0.15 \mathrm{pH}$. Further, it was found very difficult to prevent the absorption by the substrate of $\mathrm{CO}_{2}$ in sufficient amounts to change the $\mathrm{pH}$ markedly. Accordingly 2 substrates were prepared, one containing $\mathrm{HCl}$ and the other $\mathrm{NaOH}$ in sufficient amounts so that, when the substrates were mixed with serum in the proportion of $9: 1$, the $\mathrm{pH}$ of the resulting mixtures would be' approximately 8.2 and 8.7. The phospholytic activity was then determined at these two $\mathrm{pH}$ values, and the activity at $\mathrm{pH} 8.6$ was found by interpolation. The activity at $\mathrm{pH} 8.7$ was usually about twice that at $\mathrm{pH}$ 8.2.
The $\mathrm{pH}$ was determined by means of thymol blue in a Myers bicolorimeter at room temperature with a precision of $\pm 0.02 \mathrm{pH}$. The third wedge in the colorimeter was filled with potassium dichromate solution and was adjusted to match the color of each serum-substrate mixture. Preliminary work was also done with phenolphthalein and cresol red as indicators. The $\mathrm{pH}$ values with different indicators were not the same, there evidently being an unknown error due to substrate, serum proteins, or both. As we did not have facilities for checking the $\mathrm{pH}$ potentiometrically the $\mathrm{pH}$ readings reported here, while consistent with themselves, may contain a systematic error.

The $\mathrm{pH}$ of the serum-substrate mixture was found to fall somewhat during incubation, presumably owing to the liberation of phosphoric acid by the phosphatase. For 33 determinations the average $\mathrm{pH}$ change was $-0.09 \mathrm{pH}$. The $\mathrm{pH}$ change was greater the higher the initial $\mathrm{pH}$ and the greater the phospholytic activity, but the changes observed were too near the experimental error of the method for exact study of these relationships.

Bodansky (22) has reported that the phospholytic activity of sera increases about 10 per cent in 24 hours at ice box temperature, and 15 to 20 per cent in 4 to 6 hours at $37^{\circ} \mathrm{C}$. We have found that a part of this change in phospholytic activity is due to a change in the $\mathrm{pH}$ of the serum, since when a portion of a fresh serum sample is mixed with a given substrate, and another of the serum which has been kept for 24 hours at room temperature is mixed with the same substrate, the $\mathrm{pH}$ of the second mixture is significantly higher than the first. The $\mathrm{pH}$ of the substrate itself does not change appreciably in 24 hours. When proper correction for $\mathrm{pH}$ was made, the phospholytic activity of 30 sera increased an average of only 10 per cent after 24 hours at room temperature. In some cases a decrease was noted. The changes observed did not appear to be correlated with the magnitude of the initial phospholytic activity nor with diagnosis, were not much greater than the experimental error, and were not large enough to be of clinical significance. An average increase in inorganic phosphorus of $0.15 \mathrm{mgm}$. per $100 \mathrm{cc}$. or 4 per cent was 
observed in sera that had stood for 24 hours at room temperature.

\section{RESULTS}

Since liver and biliary tract disease associated with obstruction raise the serum phosphatase, and cachexia lowers it, we have not studied patients showing liver involvement nor patients in poor general condition. The icteric index was determined on all sera in the course of the measurements of $\mathrm{pH}$, so cases with mild jaundice could be detected and excluded. As most cases studied were from the out-patient department it was in general not possible to obtain fasting blood. Nearly all samples were drawn 2 to 3 hours after breakfast, so that the food factor was approximately constant. Since Bodansky and Jaffe found no difference in the average phosphatase levels in two otherwise comparable groups of blood samples, one drawn 2 to 4 hours after breakfast and the other fasting, the error from this source is probably not of clinical significance (4).

Kay (1) has reported that the variation in serum phosphatase in the normal individual is small. We have studied this further by making serial determinations on 4 healthy individuals free from bone abnormalities. The results confirm Kay's report that the normal adult variation in serum phosphatase is small. It is not likely to exceed 1 unit even when observed over long periods during which the individual's condition with respect to food, exercise and fatigue undergoes considerable change. The data for 2 cases are shown in Figures 1 and 2. In women, the

menstrual cycle does not appear to influence the serum phosphatase. The effect of various therapeutic agents will be considered later.

Belfanti et al. (23) have found that the phosphatase of rabbit liver and kidney is at its maximum activity at $\mathrm{pH} 4.5$, while the phosphatase of bone is at its maximum at $\mathrm{pH} 9.0$. Roche (9, 10) and Kay (1) report that the $\mathrm{pH}$ of maximum activity for the phosphatase of serum and of leukocytes is about 9.0, and that of erythrocytes about 6.0. Since the phosphatase of serum probably originates from several sources, and since the work of Franseen et al. $(20,21)$ and the early work of Kay (1) was done at $\mathrm{pH} 7.6$, while that of Bodansky and coworkers $(3,4,11,13,14$,
22) and of the present authors was done at $\mathrm{pH}$ 8.6, the question arose whether the different investigators have been studying the same enzyme. It also seemed possible that the different phosphatase fractions in the serum might be distin-

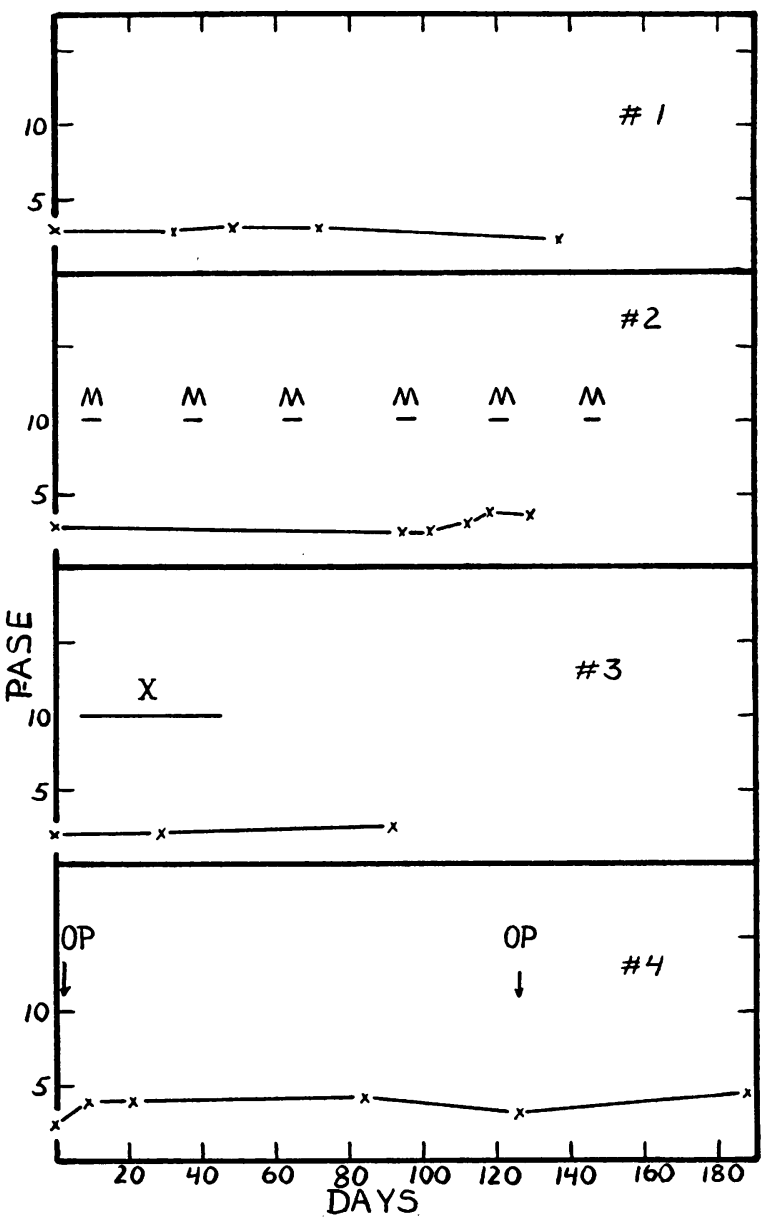

Fig. 1. Normal Male Control.

Fig. 2. Normal Female Control Showing Lack of Variation in Phosphatase with Menstruation.

Fig. 3. Retroperitoneal Sarcoma Invading Ilium; Normal Phosphatase Unchanged by Roentgen THERAPY.

Fig. 4. Osteochondrosarcoma of Fibula; Normal Phosphatase Not Significantly Changed by RepEATEd Local Excisions.

See legend to Figure 11 for abbreviations.

guished by their $\mathrm{pH}$ of maximum activity. As all our determinations have been done at two different $\mathrm{pH}$ values, we have examined the ratios of phosphatase activity over the limited $\mathrm{pH}$ range studied to see if any evidence could be obtained on these questions. 
We first determined the phospholytic activity of 13 sera at 3 or more $\mathrm{pH}$ values between $\mathrm{pH} 8.1$ and 8.8, and found that the curve obtained by plotting phosphatase units against the $\mathrm{pH}$ was a straight line within the experimental error over this $\mathrm{pH}$ range. We then found the ratio of phospholytic activity at $\mathrm{pH} 8.7$ to that at $\mathrm{pH} 8.2$ for 87 sera on which two phosphatase determinations had been made, one having been made between $\mathrm{pH} 8.10$ and 8.30 and the other between $\mathrm{pH} 8.60$ and 8.80 , the difference between the two $\mathrm{pH}$ values being at least $0.50 \mathrm{pH}$ in each case. The average value of the ratio for 59 sera for which the phospholytic activity at $\mathrm{pH} 8.6$ was normal (equal to or less than 4.0 units) was 2.2 ; the average value of the ratio for 52 sera having more than 4.0 units of phosphatase at $\mathrm{pH} 8.6$ was also 2.2. There was considerable variation in the ratios in both groups. There was not, however, any evidence that the sera with high phospholytic activity contained an enzyme having an optimum at a different $\mathrm{pH}$ from the sera of low phospholytic activity. Investigation over a wider $\mathrm{pH}$ range might, of course, show such a difference, but this seems unlikely since the degree of elevation of serum phosphatase in disease, which has been reported by investigators working at $\mathrm{pH} 7.6$ and those working at $\mathrm{pH} \mathrm{8.6,} \mathrm{has} \mathrm{been} \mathrm{about} \mathrm{the} \mathrm{same.}$

The degree of activation of the enzyme was also studied by the addition of magnesium as magnesium chloride to a final concentration of $0.005 \mathrm{M}$. It was found that the activity of the serum phosphatase was increased an average of 22 per cent in 34 determinations. This is in harmony with the findings of Kay and others (1, 24). The effect of magnesium was slightly greater in the higher $\mathrm{pH}$ range, but there was no significant difference between normal and pathological sera. Thus the effect of magnesium does not seem to be of diagnostic significance.

The diagnostic value of phosphatase determination. The results of phosphatase determinations made for diagnostic purposes are summarized in the accompanying tables. Figures for serum calcium and inorganic phosphorus were normal in all cases except those of generalized osteitis fibrosa cystica, and hence are omitted except in those cases. Table I shows the figures for serum phosphatase in normal individuals, in cases of malig-
TABLE I

Serum phosphatase with and without bone involvement

\begin{tabular}{|c|c|c|c|c|}
\hline $\begin{array}{c}\text { Case } \\
\text { num- } \\
\text { ber }\end{array}$ & $\begin{array}{l}\text { Sex } \\
\text { and } \\
\text { age }\end{array}$ & Diagnosis & $\begin{array}{c}\text { Serum } \\
\text { phosphe- } \\
\text { tase }\end{array}$ & Remarks \\
\hline $\mathbf{A}$ & years & Normals, average of 23 & $\begin{array}{c}\text { Bodansky } \\
\text { units } \\
\text { per } 100 \mathrm{cc} . \\
2.9\end{array}$ & Range, 1.7 to 5.0 \\
\hline B & \multicolumn{4}{|c|}{ Tumors without bone involvement } \\
\hline \multirow[t]{2}{*}{\begin{tabular}{r|}
1 \\
2 \\
3 \\
4 \\
5 \\
6 \\
7 \\
8 \\
9 \\
10 \\
11 \\
12 \\
13
\end{tabular}} & 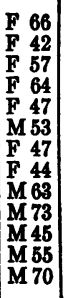 & $\begin{array}{l}\text { Myosarcoma, stomach } \\
\text { Fibroid, uterus } \\
\text { Carcinoma, breast } \\
\text { Carcinoma, breast } \\
\text { Carcinoma, breast } \\
\text { Adenosarcoma, kidney } \\
\text { Carcinoma, breast } \\
\text { Carcinoma, breast } \\
\text { Carcinoma, prostate } \\
\text { Carcinoma, prostate } \\
\text { Carcinoma, prostate } \\
\text { Carcinoma, prostate } \\
\text { Carcinoma, prostate }\end{array}$ & $\begin{array}{l}4.7 \\
2.6 \\
3.6 \\
3.8 \\
4.0 \\
3.2 \\
1.6 \\
4.1 \\
3.7 \\
3.8 \\
3.0 \\
3.8 \\
3.0\end{array}$ & \\
\hline & & Average & 3.5 & Range, 1.6 to 4.7 \\
\hline C & \multicolumn{4}{|c|}{ Benign bone tumors and allied benign lesions of bone } \\
\hline $\begin{array}{r}1 \\
2 \\
3 \\
4 \\
5 \\
6 \\
7 \\
8 \\
9 \\
10 \\
11 \\
12 \\
13 \\
14 \\
15 \\
16 \\
17\end{array}$ & $\begin{array}{l}\text { M } 60 \\
\text { M } 65 \\
\text { F } 50 \\
\text { M } 13 \\
\text { M } 17 \\
\text { M } 35 \\
\text { M } 21 \\
\text { F } 12 \\
\text { M } 10 \\
\text { M } 15 \\
\text { M } 12 \\
\text { F } 48 \\
\text { F } 29 \\
\text { F } 22 \\
\text { M } 20 \\
\text { F } 19 \\
\text { F } 17 \\
\text { F } 30 \\
\text { M } 30 \\
\text { F } 28\end{array}$ & $\begin{array}{l}\text { Osteomyelitis, tibia } \\
\text { Osteomyeliti, tibia } \\
\text { Osteomyelitis } \\
\text { Osteitis } \\
\text { Osteochondroma, humerus } \\
\text { Osteochondroma, finger } \\
\text { Osteoms, ilium } \\
\text { Osteochondroma, humerus } \\
\text { Osteochondroma, humerus } \\
\text { Osteochondroma, humerus } \\
\text { Enchondromatosis } \\
\text { Myositis ossificans } \\
\text { Calcified nodules } \\
\text { Multiple exostoses } \\
\text { Leontiasis ossium } \\
\text { Osteomyelitis } \\
\text { Epiphyseal chondromatous giant cell } \\
\text { tumor } \\
\text { Aggressive giant cell tumor, femur } \\
\text { Giant cell tumor, tibia } \\
\text { Aggressive ostooplastic giant cell tu- } \\
\text { mor }\end{array}$ & $\begin{array}{l}2.2 \\
4.4 \\
3.7 \\
5.4 \\
4.8 \\
3.0 \\
2.4 \\
8.6 \\
8.1 \\
7.3 \\
8.5 \\
3.7 \\
2.0 \\
3.2 \\
5.1 \\
2.4 \\
1.5 \\
3.8 \\
5.2 \\
8.1\end{array}$ & $\begin{array}{l}\text { Normal for age } \\
\text { Normal for age! } \\
\text { Normal for age } \\
\text { Normal for age } \\
\text { Normal for age! }\end{array}$ \\
\hline & & $\begin{array}{l}\text { Average for adults (Omitting } \\
\text { Cases } 4,8,9,10 \text { and 11) }\end{array}$ & 3.7 & Range, 1.5 to 8.1 \\
\hline
\end{tabular}

nant disease not involving bone, and in cases of non-malignant bone disease.

In the normal group the average phosphatase for 23 adults was 2.9 units with a range of 1.7 to 5.0. These figures are slightly higher than those of Bodansky and Jaffe (4). Another case not included in the table was a woman in good health without bone abnormalities or jaundice, but with a high gastric acidity, whose serum phosphatase values on two occasions were 6.6 and 5.3 units, with normal calcium and phosphorus. Eight months later the serum phosphatase had fallen to 3.5 units. This case suggests the need for caution in interpreting the presence of a high phosphatase in cases of suspected bone disease. 
The 13 cases of neoplastic disease not primary in bone and without involvement of bone or liver had serum phosphatase values within the normal range. This is in harmony with the findings of Bodansky and Jaffe (4) that malignant disease per se does not influence the serum phosphatase.

Of the 20 cases with benign bone tumors and osteomyelitis, only one (Case 20) showed an elevated serum phosphatase. This was an aggressive giant cell tumor which was laying down bone. This suggests that the bone forming characteristics of a tumor are of more importance than its malignancy in determining whether its presence will give rise to an elevated serum phosphatase.

TABLE II

Osteitis deformans and generalized osteitis fibrosa cystica

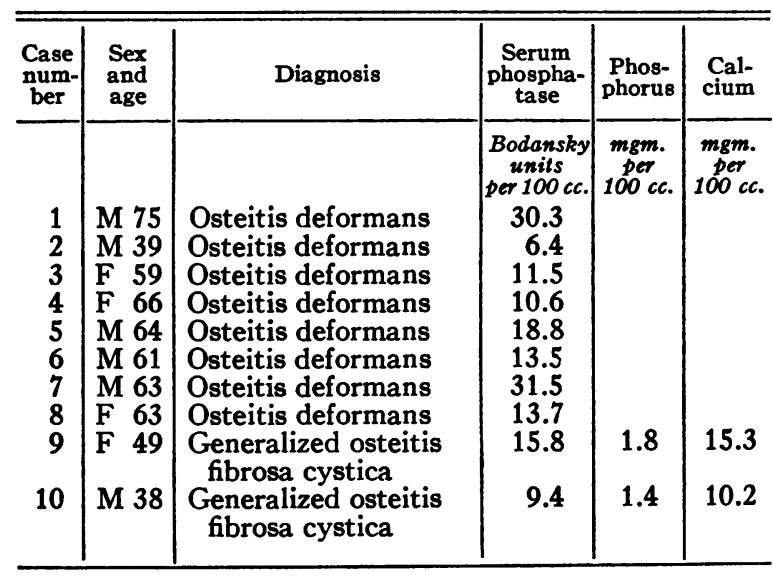

Table II shows figures for 8 cases of osteitis deformans and 2 cases of generalized osteitis fibrosa cystica. The serum phosphatase was high in all the cases of osteitis deformans, as has previously been noted by other observers (28). One of the cases of generalized osteitis fibrosa cystica showed the high serum calcium, low serum phosphorus, and high serum phosphatase usually recorded. The second case, which was clinically much more severe, had normal serum calcium, with low serum phosphorus and high serum phosphatase. The significance of this finding could not be determined without further metabolic studies on his calcium balance. Such a blood picture is not uncommon in this disease, however (Gutman, Swenson and Parsons (25)).

Table III shows the phosphatase figures for 14 cases of malignant disease not primary in bone
TABLE III

Tumors not primary in bone but with bone involvement

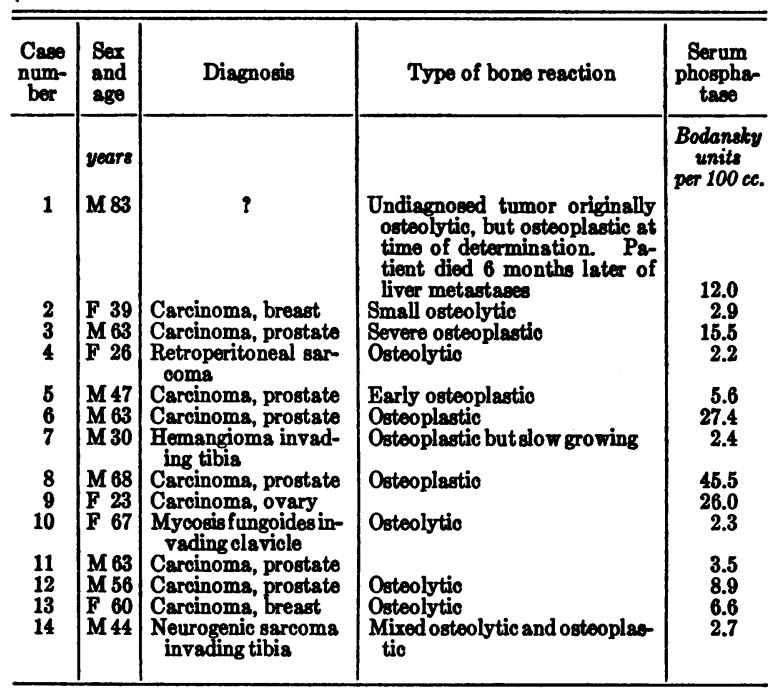

but metastatic to or invading bone. The serum phosphatase ranged from normal to 45.5 units, the highest figures being in metastatic carcinoma of the prostate. The radiographs of the patients in this group were reviewed without reference to the blood findings in order to determine whether the lesions were chiefly osteolytic or osteoplastic. The radiographic appearance was then compared with the chemical findings, and, as can be seen from the table, there is a close correlation between the two. When the bone lesion was small, very slowly progressive or chiefly osteolytic the serum phosphatase was low; widespread osteoplastic lesions on the other hand were associated with high serum phosphatase.

Our chief interest in this study was with cases having primary bone tumors, since Franseen et al. $(20,21)$ has suggested that serum phosphatase determinations are of value for diagnosis and prognosis in such cases. Our observations are summarized in Table IV. In the osteoplastic type of osteogenic sarcoma the serum phosphatase is usually elevated, while in the osteolytic type of osteogenic sarcoma, in chondrosarcoma, and in endothelial myeloma the serum phosphatase is normal or only slightly raised. The correlation between phosphatase figures and either the histological or radiographic type of the tumor is not close, and the phosphatase findings can only be 
TABLE IV

Malignant tumors primary in bone

\begin{tabular}{|c|c|c|c|c|}
\hline $\begin{array}{l}\text { Cave } \\
\text { num- } \\
\text { ber }\end{array}$ & $\begin{array}{l}\text { Sex } \\
\text { and } \\
\text { age }\end{array}$ & Diagnods & Type of bone reaction & $\begin{array}{c}\text { Serum } \\
\text { phospha- } \\
\text { tase }\end{array}$ \\
\hline & years & & & $\begin{array}{l}\text { Bodansky } \\
\text { units } \\
\text { per } 100 \text { ce. }\end{array}$ \\
\hline 1 & M 40 & $\begin{array}{l}\text { Chondrosarooma, } \\
\text { femur }\end{array}$ & Chiefly osteoplastic & 7.5 \\
\hline${ }_{3}^{2 *}$ & $\begin{array}{l}\mathrm{F} 26 \\
\mathrm{M} 28\end{array}$ & $\begin{array}{l}\text { Osteogenic sarcoma } \\
\text { Osteogenic sarcoma, }\end{array}$ & Osteoplastic & $\begin{array}{r}9.8 \\
13.2\end{array}$ \\
\hline 4 & M 23 & Osteogenicsarcoma, & Osteolytic & 5.6 \\
\hline $\boldsymbol{5}$ & M 18 & Osteogenic sarcoms, & Osteoplastic & 13.7 \\
\hline $6^{*}$ & M 24 & Ostoogenicsarcoms, & Osteolytic & 6.7 \\
\hline 7 & M 38 & Osteogenicsarcoma, & Small osteolytic & 2.9 \\
\hline 8 & M 73 & Osteogenic sarcoma, & Osteolytic & 3.1 \\
\hline$\theta$ & M 12 & $\begin{array}{l}\text { Osteogenic } \\
\text { femur }\end{array}$ & $\begin{array}{l}\text { Osteoplastic. Phosphatase high } \\
\text { for age }\end{array}$ & 17.9 \\
\hline 10 & F 11 & Osteogenic sarcoma & Mixed osteoplastic and osteolytic. & 3.8 \\
\hline 11 & M $\mathbf{x}$ & Ostoogeniosarcoms, & Osteolytic & 4.1 \\
\hline 12 & M 30 & $\begin{array}{l}\text { Low gradeosteo- } \\
\text { ohondrosarcoma, } \\
\text { fibula-from my- }\end{array}$ & Osteoplastic & 2.6 \\
\hline 13 & M 27 & $\begin{array}{l}\text { Osteochondrosar- } \\
\text { coma, rib }\end{array}$ & Small mired osteoplastic and os- & 3.9 \\
\hline 14 & M 45 & Ostoochondrosar- & Chiefy osteoplastic & 4.2 \\
\hline 15 & F 55 & Chondromyzosar- & Osteolytic & 2.4 \\
\hline 16 & M 33 & Atypioalmalignant & Osteolytic & 4.3 \\
\hline 17 & $\mathbf{M} 21$ & Endothelial myo- & Chiefly osteolytic, very slow & 4.0 \\
\hline 18 & F 19 & Endothelial myo- & Slow osteoplasia & 3.7 \\
\hline 19 & F 16 & $\begin{array}{l}\text { Endothelial myo- } \\
\text { loma, femur }\end{array}$ & $\begin{array}{l}\text { Osteolytic, with osteoplastic callus } \\
\text { formation }\end{array}$ & 5.0 \\
\hline 20 & M 48 & Endothelial mye- & Osteolytic & 6.0 \\
\hline 21 & F 37 & Endothelial myo- & Osteolytic & 2.7 \\
\hline 22 & F 8 & $\begin{array}{l}\text { Endothelial mye- } \\
\text { loms, rib }\end{array}$ & $\begin{array}{l}\text { Osteolytic. Phosphatase normal } \\
\text { for age }\end{array}$ & 6.7 \\
\hline
\end{tabular}

* Diagnosis by radiographs only, no biopsy.

considered as suggestive, rather than definitely diagnostic of the type of tumor studied.

The prognostic significance of phosphatase determinations. In theory, when a tumor such as osteogenic sarcoma is present and is pouring large quantities of phosphatase into the blood stream, the removal of the tumor by operation, or its inactivation by radiation or toxins should result in a fall in serum phosphatase. The extent and constancy of the drop should be an indication of the effectiveness of the treatment, a late rise in phosphatase indicating the presence of recurrence or metastases. Franseen and coworkers have reported this to be the case $(20,21)$. On the other hand, if the tumor present is one such as endothelial myeloma, which is not a source of excessive phosphatase, its removal should not affect the serum phosphatase. We have studied a number of cases during therapy in the hope that serial phosphatase determinations would prove to be a reliable guide in prognosis.

It was necessary first to determine whether the therapeutic procedures, operation, irradiation, and the administration of Coley's toxins, would in themselves influence the serum phosphatase. Accordingly we made serial determinations on fifteen patients whose initial serum phosphatase was normal or only slightly raised. The observations for two typical cases are shown in Figures 3 and 4. The phosphatase was not significantly raised in any case following irradiation alone. The slight drop in phosphatase observed in two cases following irradiation may have been due to treatment, but was too small to be of much significance. Irradiation alone, therefore, appears to be without effect on normal phosphatase. In one case in this series where operation was followed by the administration of toxins, and in one case where irradiation was followed by the administration of toxins, there was a marked rise in phosphatase. In the cases with a high initial reading, which are discussed more fully later, there was a marked rise in phosphatase in two cases following operation and the administration of toxins and in two cases following irradiation and injection of toxins. It seems probable, though the rise in phosphatase during toxin therapy is not constant, that phosphatase determinations made during a course of toxins are without significance in prognosis.

The effect of operation is difficult to evaluate. Bodansky and Jaffe (4) have reported a drop in serum phosphatase following operations not involving bone, but this may have been due to poor nutrition during the postoperative period. Since we have observed a slight rise in serum phosphatase on 3 occasions following bone operations, and since Hunsberger and Ferguson (26) and Smith and Maizels (18) have shown that there is a rise in serum phosphatase during the healing of fractures, it is likely that the serum phosphatase may be somewhat elevated following any operative procedure involving considerable bone trauma.

The second series of charts, Figures 5 to 11 inclusive, shows the changes during treatment in 


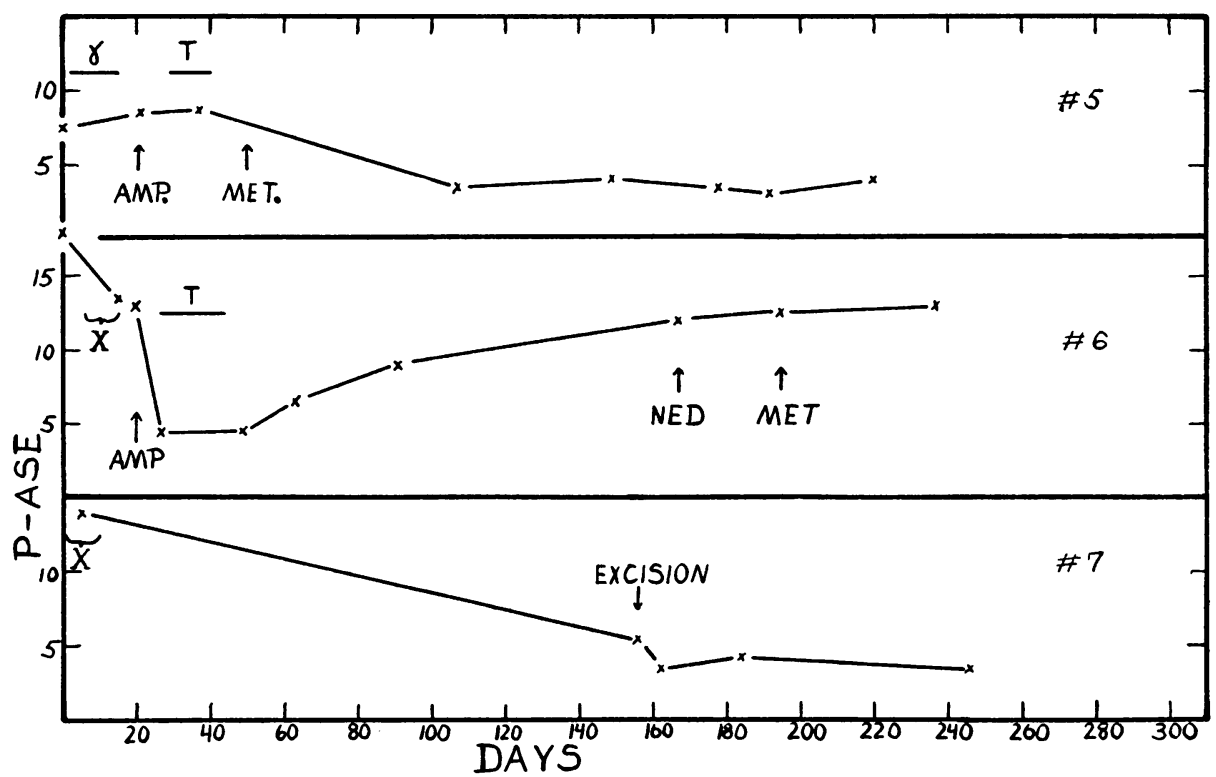

Fig. 5. Osteogenic Sarcoma of Femur; Moderately High Initial Phosphatase Remaining Elevated during Treatment by Radium, Amputation and Toxins, but Later Falling to Normal in Spite of Increasingly Extensive Pulmonary Metastases.

Fig. 6. Osteogenic Sarcoma of Femur; High Initial Phosphatase Falling under Roentgen Therapy, Becoming Normal after Amputation in Spite of Toxin Therapy, and then Rising Slowly Probably Because of the Onset of Puberty.

Fig. 7. Osteogenic Sarcoma of Tibia; High Phosphatase Falling after Roentgen Therapy Resulting in Roentgen Necrosis of the Tumor, with Further Fall after LOCAL ExCISION.

See legend to Figure 11 for abbreviations.

5 patients with osteogenic sarcoma, one with an endothelial myeloma, and one with an aggressive giant cell tumor, all of whom had a high initial serum phosphatase. These are chosen as typical examples from a series of 12 such cases. In two (Figures 6 and 9) there was a prompt drop following amputation, which was maintained during a subsequent course of toxins. One of these cases (aged 121/2 years) subsequently showed a marked rise in phosphatase coincident with an increase in the rate of body growth. Four months later he showed evidence of lung metastases. On the other hand, in two cases (Figures 5 and 8) there was a more or less marked rise in phosphatase during treatment. In both, the phosphatase later fell to high normal levels, but one has remained free of disease and the other now has advanced lung metastases. A third case which has been followed for only five weeks had a similar rise in phosphatase during therapy. In addition to these cases who developed lung metastases while under observation, we have seen two other cases who already had lung metastases at the time of our first phosphatase determinations. In one the primary tumor had been removed by amputation, in the other the primary had recurred in the adjacent soft parts after temporary inactivation by irradiation. In both, the serum phosphatase was within normal limits. It seems from these charts that the serum phosphatase is so variable during the course of treatment, especially by toxins, that determinations made at such times are without value in prognosis, and that, even in the absence of other factors, the serum phosphatase can not be relied upon to detect early metastases. We feel therefore that, at present, no reliance can be placed on phosphatase determinations as an aid in prognosis.

\section{DISCUSSION}

On examination of the above data we are brought to the conclusion that serum phosphatase activity is a measure of the amount of new bone formation taking place in the body, or of an attempt on the part of the body to form new bone, 


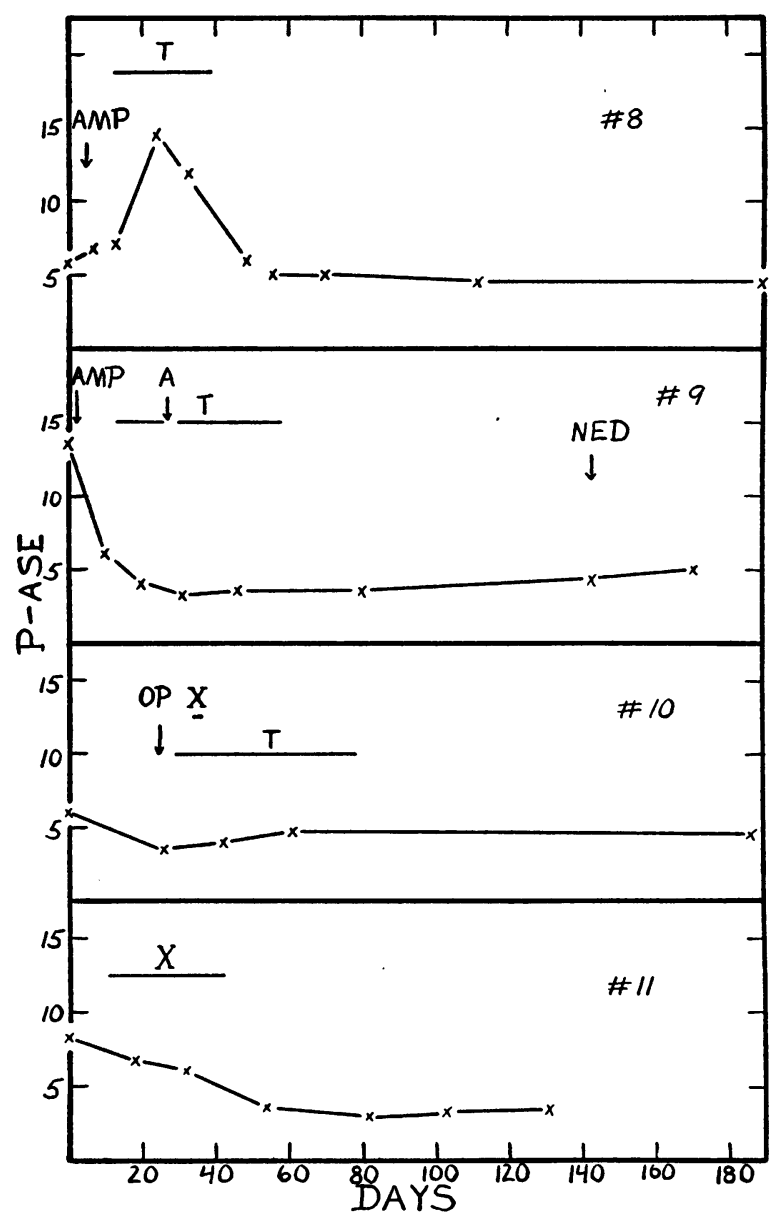

Fig. 8. Osteogenic Sarcoma of Humerus; Slightly Elevated Initial Phosphatase Showing Slight Rise after Amputation, Marked Rise during Toxin Therapy, with a Subsequent Drop to High Normal Level.

Fig. 9. Osteogenic Sarcoma of Femur; High Initial Phosphatase with Prompt Drop to Normal after Amputation and No Change after AppendecTOMY AND TOXIN THERAPY.

Fig. 10. Endothelial Myeloma of Ulna; Slightly Raised Initial Phosphatase Showing Little Change Following Local Excision aNd RoEntgen aNd Toxin THERAPY.

Fig. 11. Aggressive Giant Cell Tumor of Femur; High Initial Phosphatase with Progressive Fall Following Roentgen Therapy.

Abbreviations used in Figures

$\mathrm{X}$-Roentgen therapy.

$\gamma$-Radium therapy.

T-Coley's toxins therapy.

OP-Excision or curettage.

AMP-Amputation.

NED-No evidence of disease.

MET-Pulmonary metastases. and is in no sense a unique and characteristic indication of the presence of any one type of bone tumor. It is possible that phosphatase readings are high in generalized osteitis fibrosa cystica and osteitis deformans because the body is attempting to repair defects due to metabolic disorder. They are often high in osteogenic sarcoma because this tumor frequently forms new bone, but they may be low because the particular tumor is not forming bone. Lung metastases are usually not osteoplastic in character although Brunschwig and Harmon (27) believe osteoplastic metastases occur more frequently than is generally supposed. None of our four cases with lung metastases from osteogenic sarcoma showed any radiographic evidence of bone formation in the lungs, however. This probably explains why three of the cases had normal serum phosphatase values, while the fourth showed only a high normal for an actively growing boy of his age.

Although the figures for serum phosphatase are not definitely characteristic for any type of tumor, we feel that they are of diagnostic significance. For instance they may differentiate a growing tumor with a high rate of osteoplastic activity such as osteogenic sarcoma, a less actively ossifying tumor such as chondrosarcoma, or a very slowly changing or stationary bony abnormality such as an osteoma or an old myositis ossificans, tumors which may show almost indistinguishable roentgenological pictures. In interpreting the phosphatase findings it must be remembered that callus formation around a healing pathological fracture through the site of an osteolytic tumor may cause an elevation in the serum phosphatase, even though the tumor itself may not produce much phosphatase.

\section{SUM MARY}

Determinations of serum phosphatase have been made by a modification of Bodansky's method on normal individuals and on cases of neoplastic disease of the bone.

The phosphatase of normal serum did not appear to differ from that of pathological serum in degree of activation as measured by the activat-

\footnotetext{
M (Chart No. 2)-Menstruation.

A (Chart No. 9)-Appendectomy.

$\mathrm{P}$-ase-Serum phosphatase in Bodansky units.
} 
ing effect of magesium or in $\mathrm{pH}$ of optimum activity.

The serum phosphatase was found to be normal or very slightly raised in chronic osteitis, osteomyelitis, benign bone tumors, endothelial myeloma, and chondrosarcoma, and high in osteitis deformans, generalized osteitis fibrosa cystica, osteoplastic metastatic disease, and some cases of osteogenic sarcoma, particularly those in which there is radiographic evidence of considerable bone production.

Serum phosphatase determinations were not found to be of value in detecting pulmonary metastases.

\section{BIBLIOGRAPHY}

1. Kay, H. D., Plasma phosphatase. I. Method of determination. Some properties of the. enzyme. J. Biol. Chem., 1930, 89, 235.

II. The enzyme in disease, particularly in bone disease. J. Biol. Chem., 1930, 89, 249.

2. Jenner, H. D., and Kay, H. D., Plasma phosphatase. III. A clinical method for the determination of plasma phosphatase. Brit. J. Exper. Path., 1932, $13,22$.

3. Bodansky, A., with the assistance of Hallman, L. F., and Bonoff, R., Phosphatase studies. I. Determination of inorganic phosphate. Beer's law and interfering substances in the Kuttner-Lichtenstein method. J. Biol. Chem., 1932-33, 99, 197.

4. Bodansky, A., and Jaffe, H. L., Phosphatase studies. III. Serum phosphatase in diseases of the bone; interpretation and significance. Arch. Int. Med., 1934, 54, 88.

5. Palmer, L. S., and Nelson, J. W., Comparison of Jenner-Kay and Bodansky methods for determining phosphatase in plasma and serum. Proc. Soc. Exper. Biol. and Med., 1934, 31, 1070.

6. King, E. J., and Armstrong, A. R., A convenient method for determining serum and bile phosphatase activity. Canad. Med. A. J., 1934, 31, 376.

7. Stanford, R. V., and Wheatley, A. H. M., The distribution of phosphorus compounds in blood. Biochem. J., 1925, 19, 706.

8. Roberts, W. M., Variations in the phosphatase activity of the blood in disease. Brit. J. Exper. Path., 1930, 11, 90.

9. Roche, J., and Latreille, M., Sur les phosphatases du sang et de l'hemolymphe. Compt. rend. Soc. de biol., 1934, 116, 1033.

10. Roche, J., Importance du substrat pour le pH optimum d'action des phosphatases sanguines (globules blancs et rouges, sérum). Compt. rend. Soc. de biol., 1931, 107, 640 .

11. Bodansky, A., with the technical assistance of Hallman, L. F., and Bonoff, R., Phosphatase studies. VI. Non-osseous origins of serum phosphatase. Its increase after ingestion of carbohydrates. J. Biol. Chem., 1934, 104, 473.
12. Robison, R., The possible significance of hexosephosphoric esters in ossification. Biochem. J., 1923, $17,286$.

13. Bodansky, A., and Jaffe, H. L., Phosphatase studies. IV. Serum phosphatase of non-osseous origin. Significance of the variations of serum phosphatase in jaundice. Proc. Soc. Exper. Biol. and Med., 1933, 31, 107.

14. Bodansky, A., with the technical assistance of Hallman, L. F., and Bonoff, R., Phosphatase studies. VII. Inorganic phosphorus and phosphatase of the serum in new born puppies. J. Biol. Chem., 1934, 104, 717.

15. Binet, L., and Pautrat, J., La phosphatase plasmatique au cours du diabète pancréatique expérimental. Compt. rend. Soc. de biol., 1934, 116, 709.

16. Roberts, W. M., Blood phosphatase and the Van den Bergh reaction in the differentiation of the several types of jaundice. Brit. M. J., 1933, 1, 734.

17. Armstrong, A. R., King, E. J., and Harris, R. I., Phosphatase in obstructive jaundice. Canad. M. A. J., 1934, 31, 14.

18. Smith, J., and Maizels, M., The plasma phosphatase in rickets and scurvy. Arch. Dis. Childhood, 1932, $7,149$.

19. Smith, J., Plasma phosphatase in rickets and other disorders of growth. Arch. Dis. Childhood, 1933, $8,215$.

20. Franseen, C. C., and McLean, R., The phosphatase activity of tissues and plasma in tumors of bone. Am. J. Cancer, 1935, 24, 299.

21. Simmons, C. C., and Franseen, C. C., The diagnostic value of phosphatase determinations in the study of bone tumors. Ann. Surg., 1935, 102, 555.

22. Bodansky, A., with the assistance of Hallman, L. F., and Bonoff, R., Phosphatase studies. II. Determination of serum phosphatase. Factors influencing the accuracy of the determination. J. Biol. Chem., 1933, 101, 93.

23. Belfanti, S., Contardi, A., and Ercoli, A., Researches on the phosphatases. II. Inactivation and reactivation of the phosphatases of animal organs. Biochem. J., 1935, 29, 842.

24. Hommerberg, C., Uber Mg-Aktivierung von tierischen Phosphatasen beigeringen Enzymkonzentrationen. I. Biochem. Ztschr., 1933, 258, 154.

25. Gutman, A. B., Swenson, P. C., and Parsons, W. B., The differential diagnosis of hyperparathyroidism. J. A. M. A., 1934, 103, 87.

26. Hunsberger, A., and Ferguson, L. K., Variations in phosphatase and in inorganic phosphorus in serum during fracture repair. Arch. Surg., 1932, 24, 1052.

27. Brunschwig, A., and Harmon, P. H., Studies in bone sarcoma. I. Malignant osteoblastomata as evidence for the existence of true osteoblasts. Surg., Gynec. and Obstet., 1933, 57, 711.

28. Gutman, A. B., and Gutman, E. B., Paget's disease: Relative constancy of serum phosphatase levels over periods up to 2 years. Proc. Soc. Exper. Biol. and Med., 1935, 33, 150. 